\title{
Assessment of Genetic Variability and Inter-Character Association Studies in Rice Genotypes (Oryza sativa L.)
}

\author{
Harsha*, Indra Deo, Sudhir Kumar and Mohammed Talha
}

\author{
Department of Genetics and Plant Breeding, College of Agriculture, GBPAU\&T, \\ Pantnagar, Uttarakhand - 263145, India \\ *Corresponding author
}

\section{A B S T R A C T}

\begin{tabular}{|l|}
\hline Ke y w o r d s \\
Genetic variability, \\
Correlation, Path \\
analysis, \\
Genotypes, Yield \\
traits and Rice.
\end{tabular}

The present study was undertaken on twenty-nine genotypes of rice to determine, genetic variability, the nature of association among different yield attributes and their direct and indirect contribution towards yield. A high degree of variation was observed for all characters studied. Estimates of PCV and GCV were higher for the number of effective tillers per plant, flag leaf area, yields per plant and for test weight. Small differences between GCV and PCV were recorded for all the characters studied which indicated less influence of environment on these characters. The presence of high heritability with high genetic advance showed additive effects of the gene on the character and theyresponse to selection effectively as they are least affected by the environmental condition. Grain yield per plant showed the significant positive correlation number of effective tillers per plant, panicle length and test weight. The result of path analysis indicated number of effective tillers per plant had a highest positive direct effect on grain yield per plant followed by flag leaf area, days to maturity, panicle length and leaf length.

\section{Introduction}

Rice (Oryza sativa L.) belonging to the family of grasses Gramineae (Poaceae), is one of the important food crops among three major food crops in the world and forms the main diet of about more than half of the world's population. The area under rice cultivation is estimated to be 160.07 million hectares with global production 483.81 Million tons (USDA, 2017). Asia shares 90 percent production of rice alone and ranked first in production. Rice accounts for about 42 per cent of total food grain production and $>55$ per cent of diet in India. The production is very low in India due to non-availability of high yielding varieties.
A better understanding of the relationship between grain yield and its component traits becomes necessary for making an efficient selection for the development of new varieties with improved economically important traits (Kumar et al., 2013). Development of high yielding varieties requires the knowledge of existing genetic variability. A critical estimate of genetic variability is pre-requisite for initiating appropriate breeding procedure in crop improvement programme. The Genetic parameters such as genotypic coefficient of variation $(\mathrm{GCV})$ and phenotypic coefficient of variation $(\mathrm{PCV})$ are useful in detecting the amount of variability present in the 
germplasm. Heritability coupled with high genetic advance would be a more useful tool in predicting the resultant effect in the selection of the best genotypes for yield and its attributing traits (Singh et al., 2011). Correlation (both phenotypic and genotypic) studies among yield and its component traits give a better insight towards the relationship between them (Jayasudha and Sharma, 2010). Genotypic correlation plays a key role in the development and execution of suitable breeding programs (Selvaraj et al., 2011).

Path analysis provides a method of partitioning the correlation coefficient into direct and indirect effect and measures relative importance of causal factors involved (Dewy and Lu, 1959). With the above background information, the present investigation was undertaken to study the genetic parameters, correlation and path analysis among the twenty-nine rice genotypes.

\section{Materials and Methods}

The field experiments were carried out in two consecutive kharif season of 2014 and 2015 at Norman E Borlaug Crop Research Centre (NEBCRC) of G.B. Pant University of Agriculture and Technology, Pantnagar (Uttarakhand). The research materials for present study compromised of twenty-nine lines of rice genotypes which included Basmati and Non-basmati types. Twenty-nine lines of rice genotypes were grown in a randomized block design (RBD) with three replications. The test plot consisted of 3 rows of $6 \mathrm{~m}$ length with a row to row and plant to plant spacing of $20 \mathrm{~cm}$ and $15 \mathrm{~cm}$, respectively. Cultural practices like weeding, irrigation and recommended dose of fertilizer were applied to obtain a good crop growth. The observations were recorded on 5 randomly selected competitive plants in each plot for following characters: day to $50 \%$ flowering, days to maturity, no. of effective tillers per plant, panicle length $(\mathrm{cm})$, leaf length $(\mathrm{cm})$, leaf width $(\mathrm{cm})$, flag leaf area $\left(\mathrm{cm}^{2}\right)$,test weight $(\mathrm{g})$ and grain yield per plant (g).

\section{Results and Discussion}

The analysis of variance revealed that all the genotypes showed a significant difference for all the characters studied. The source of any kind of selection depends on the existence of the genetic variability. The presence of significant amount of variability in the initial breeding material assures the production of suitable recombinants for crop improvement. Previous studies in rice also found a significant variation for these traits The estimate of the mean, range, the phenotypic coefficient of variation (PCV), the genotypic coefficient of variation (GCV), heritability, genetic advance and genetic advance (as a percent of mean) were presented in table 1 . Phenotypic coefficients of variation were higher than the corresponding genotypic coefficients of variation, indicating the considerable influence of the environment on the expression of the traits. Estimates of PCV and GCV were higher for the number of effective tillers per plant, flag leaf area, yields per plant and for test weight. Phenotypic coefficients of variation (PCV) and Genotypic coefficients of variation (GCV) ranged from $10.45 \%, 9.57$ for panicle length to $48.62 \%$, $47.79 \%$ for grain yield per plant. The similar finding also confirmed by (Tuwaret al., 2013) for high GCV and PCV for the plant height number of tillers per plant, number of effective tillers per plant, grain yield per plant and 1000 grain weight. Bastia et al., (2008) also reported high PCV and GCV in upland rice for grain yield per plant, number of effective tillers per plant and number of grains per panicle. The close association found between the phenotypic and genotypic coefficient of variation which is further supported by high values of heritability of the characters studied. 
Table.1 General Mean (GM), Standard error, Range and variability parameters for yield and yield component characters

\begin{tabular}{|l|l|l|l|l|l|l|l|l|}
\hline S. No & Characters & Mean & S.E & Range & PCV (\%) & GCV (\%) & $\mathbf{h}^{2}(\%)$ & GA (as \% of mean) \\
\hline 1 & Days to 50\% flowering & 111.95 & 1.22 & $71-139$ & 18.27 & 18.17 & 98.93 & 37.23 \\
\hline 2 & Days to maturity & 132.85 & 1.74 & $93-163$ & 15.54 & 15.37 & 97.86 & 31.32 \\
\hline 3 & Plant height $(\mathbf{c m})$ & 126.00 & 2.59 & $91.32-174.10$ & 19.55 & 19.22 & 96.67 & 38.93 \\
\hline 4 & No. of effective tillers/ plant & 13.00 & 0.47 & $4-17$ & 24.37 & 23.55 & 93.41 & 46.88 \\
\hline 5 & Panicle length $(\mathbf{c m})$ & 29.06 & 0.70 & $24.20-35.50$ & 10.45 & 9.57 & 83.83 & 18.04 \\
\hline 6 & Leaf length(cm) $(\mathbf{c m})$ & 38.47 & 0.24 & $21.95-78.09$ & 30.33 & 30.31 & 99.88 & 62.40 \\
\hline 7 & Leaf width $(\mathbf{c m})$ & 1.37 & 0.02 & $1.01-2.13$ & 24.16 & 23.97 & 98.41 & 48.98 \\
\hline 8 & Flag leaf area $(\mathbf{c m} \mathbf{2})$ & 32.04 & 2.55 & $17.05-68.19$ & 35.57 & 32.78 & 84.94 & 62.24 \\
\hline 9 & Grain yield/plant $(\mathbf{g})$ & 15.38 & 0.80 & $9.68-39.40$ & 48.62 & 47.79 & 96.60 & 96.76 \\
\hline 10 & Test weight $(\mathbf{g})$ & 13.31 & 0.27 & $6.78-24.35$ & 39.29 & 39.11 & 99.08 & 80.19 \\
\hline
\end{tabular}

Table.2 Inter character correlation coefficient between different characters at phenotypic and genotypic level in rice genotypes

\begin{tabular}{|c|c|c|c|c|c|c|c|c|c|c|}
\hline Characters & $\begin{array}{l}\text { Days to } \\
50 \% \\
\text { flowering }\end{array}$ & $\begin{array}{l}\text { Days to } \\
\text { maturity }\end{array}$ & $\begin{array}{l}\text { Plant } \\
\text { height } \\
\text { (cm) }\end{array}$ & $\begin{array}{l}\text { No. of } \\
\text { effective } \\
\text { tillers/ plant }\end{array}$ & $\begin{array}{l}\text { Panicle } \\
\text { length } \\
(\mathrm{cm})\end{array}$ & $\begin{array}{l}\text { Leaf } \\
\text { length } \\
(\mathrm{cm})\end{array}$ & $\begin{array}{l}\text { Leaf } \\
\text { width } \\
\text { (cm) }\end{array}$ & $\begin{array}{l}\text { Flag leaf } \\
\text { area } \\
(\mathrm{cm} 2)\end{array}$ & $\begin{array}{l}\text { Grain } \\
\text { yield/plant } \\
\text { (g) }\end{array}$ & $\begin{array}{l}\text { Test } \\
\text { weight } \\
\text { (g) }\end{array}$ \\
\hline $\begin{array}{l}\text { Days to 50\% } \\
\text { flowering }\end{array}$ & 1.00 & $0.988 * *$ & $0.548 * *$ & $0.357 * *$ & $0.078^{\mathrm{NS}}$ & $0.058^{\mathrm{NS}}$ & $0.065^{\mathrm{NS}}$ & $0.086^{\mathrm{NS}}$ & $-0.497 * *$ & $-0.305^{* *}$ \\
\hline Days to maturity & $0.978 * *$ & 1.00 & $0.625 * *$ & $0.380 * *$ & $0.098^{\mathrm{NS}}$ & $0.018^{\mathrm{NS}}$ & $0.099^{\mathrm{NS}}$ & $0.131^{\mathrm{NS}}$ & $-0.499 * *$ & $-0.305 * *$ \\
\hline Plant height (cm) & $0.533 * *$ & $0.603 * *$ & 1.00 & $0.538 * *$ & $0.259 *$ & $-0.287 * *$ & $0.230 *$ & $0.207^{\mathrm{NS}}$ & $-0.457 * *$ & $-0.364 * *$ \\
\hline $\begin{array}{l}\text { No. of effective } \\
\text { tillers/ plant }\end{array}$ & $0.336 * *$ & $0.354 * *$ & $0.520 * *$ & 1.00 & $-0.279 * *$ & $-0.345^{* *}$ & $0.423 * *$ & $0.313 * *$ & $0.491 * *$ & $0.494 * *$ \\
\hline Panicle length $(\mathrm{cm})$ & $0.058 \mathrm{NS}$ & $0.078 \mathrm{NS}$ & $0.234 *$ & -0.228 & 1.00 & $0.293 * *$ & $-0.202^{\mathrm{NS}}$ & $-0.031^{\mathrm{NS}}$ & $0.038^{\mathrm{NS}}$ & $-0.127^{\mathrm{NS}}$ \\
\hline Leaf length(cm) & $0.057 \mathrm{NS}$ & $0.017 \mathrm{NS}$ & $-0.282 * *$ & $-0.332 * *$ & $0.270 *$ & 1.00 & $-0.165^{\mathrm{NS}}$ & $-0.002^{\mathrm{NS}}$ & $0.192^{\mathrm{NS}}$ & $-0.035^{\mathrm{NS}}$ \\
\hline Leaf width $(\mathrm{cm})$ & $0.063 \mathrm{NS}$ & $0.098 \mathrm{NS}$ & $0.222 *$ & $0.411 * *$ & $-0.188 \mathrm{NS}$ & $-0.163 \mathrm{NS}$ & 1.00 & $0.794 * *$ & $-0.139^{\mathrm{NS}}$ & $-0.288 * *$ \\
\hline Flag leaf area $(\mathrm{cm} 2)$ & $0.068 \mathrm{NS}$ & $0.121 \mathrm{NS}$ & $0.181 \mathrm{NS}$ & $0.285^{* *}$ & $-0.018 \mathrm{NS}$ & $0.002 \mathrm{NS}$ & $0.734 * *$ & 1.00 & $0.019^{\mathrm{NS}}$ & $0.174^{\mathrm{NS}}$ \\
\hline $\begin{array}{l}\text { Grain yield/plant } \\
\text { (g) }\end{array}$ & $-0.488 * *$ & $-0.490 * *$ & $-0.443 * *$ & $0.461 * *$ & $0.038 \mathrm{NS}$ & $0.191 \mathrm{NS}$ & $-0.140 \mathrm{NS}$ & $0.019 \mathrm{NS}$ & 1.00 & $0.307 * *$ \\
\hline Test weight (g) & $-0.303 * *$ & $-0.302 * *$ & $-0.356 * *$ & $0.476^{* *}$ & $0.117 \mathrm{NS}$ & $-0.036 \mathrm{NS}$ & $-0.285^{* *}$ & $0.163 \mathrm{NS}$ & $0.304 * *$ & 1.00 \\
\hline
\end{tabular}


Table.3 Path coefficient analysis showing the direct and indirect effect of characters on grain yield at phenotypic and genotypic level

\begin{tabular}{|c|c|c|c|c|c|c|c|c|c|c|c|}
\hline \multirow[b]{2}{*}{ Characters } & & \multirow[b]{2}{*}{$\begin{array}{c}\text { Correlation } \\
\text { with grain } \\
\text { yield }\end{array}$} & \multicolumn{9}{|c|}{ Indirect effect via } \\
\hline & & & $\begin{array}{c}\text { Days to } \\
50 \% \\
\text { flowering }\end{array}$ & $\begin{array}{l}\text { Days to } \\
\text { maturity }\end{array}$ & $\begin{array}{c}\text { Plant } \\
\text { height } \\
(\mathrm{cm})\end{array}$ & $\begin{array}{c}\text { No. of } \\
\text { effective } \\
\text { tillers/ plant }\end{array}$ & $\begin{array}{c}\text { Panicle } \\
\text { length } \\
(\mathrm{cm})\end{array}$ & $\begin{array}{c}\text { Leaf } \\
\text { length } \\
(\mathrm{cm})\end{array}$ & $\begin{array}{c}\text { Leaf } \\
\text { width }(\mathrm{cm})\end{array}$ & $\begin{array}{c}\text { Flag leaf } \\
\text { area } \\
\left(\mathrm{cm}^{2}\right)\end{array}$ & $\begin{array}{c}\text { Test } \\
\text { weight } \\
\text { (g) }\end{array}$ \\
\hline \multirow{2}{*}{$\begin{array}{c}\text { Days to } 50 \% \\
\text { Flowering }\end{array}$} & $\mathrm{P}$ & $-0.488 * *$ & -0.300 & -0.299 & -0.163 & 0.103 & -0.018 & -0.018 & -0.019 & -0.021 & 0.093 \\
\hline & $\mathrm{G}$ & $-0.497 * *$ & -0.581 & -0.574 & -0.319 & -0.210 & -0.046 & -0.033 & -0.038 & -0.050 & 0.177 \\
\hline \multirow{2}{*}{$\begin{array}{l}\text { Days to } \\
\text { maturity }\end{array}$} & $\mathrm{P}$ & $-0.490 * *$ & -0.070 & -0.072 & -0.043 & 0.026 & -0.006 & -0.001 & -0.007 & -0.009 & 0.022 \\
\hline & $\mathrm{G}$ & $-0.499 * *$ & 0.218 & 0.220 & 0.138 & 0.084 & 0.022 & 0.004 & 0.022 & 0.029 & -0.067 \\
\hline \multirow{2}{*}{$\begin{array}{c}\text { Plant } \\
\text { height }(\mathrm{cm})\end{array}$} & $\mathrm{P}$ & $-0.443 * *$ & -0.005 & -0.005 & -0.009 & -0.005 & -0.002 & 0.003 & -0.002 & -0.002 & 0.003 \\
\hline & $\mathrm{G}$ & $-0.457 * *$ & -0.004 & -0.004 & -0.006 & -0.003 & -0.002 & 0.002 & -0.001 & -0.001 & 0.002 \\
\hline \multirow{2}{*}{$\begin{array}{l}\text { No. of effective } \\
\text { tillers/ plant }\end{array}$} & $\mathrm{P}$ & $0.461 * *$ & -0.105 & -0.110 & -0.162 & 0.311 & 0.071 & 0.103 & -0.128 & -0.089 & 0.148 \\
\hline & $\mathrm{G}$ & $0.491 * *$ & -0.142 & -0.151 & 0.214 & 0.397 & 0.111 & 0.137 & -0.168 & -0.124 & 0.196 \\
\hline \multirow{2}{*}{$\begin{array}{c}\text { Panicle length } \\
\text { (cm) }\end{array}$} & $\mathrm{P}$ & $0.038^{\mathrm{NS}}$ & -0.008 & -0.010 & -0.031 & 0.030 & 0.133 & -0.036 & 0.025 & 0.002 & 0.015 \\
\hline & $\mathrm{G}$ & $0.038^{\mathrm{NS}}$ & -0.015 & -0.019 & 0.050 & 0.053 & 0.191 & -0.056 & 0.039 & 0.006 & 0.024 \\
\hline \multirow{2}{*}{$\begin{array}{l}\text { Leaf length } \\
(\mathrm{cm})\end{array}$} & $\mathrm{P}$ & $0.191^{\mathrm{NS}}$ & 0.007 & 0.002 & -0.034 & -0.039 & 0.032 & 0.120 & -0.020 & 0.000 & -0.004 \\
\hline & G & $0.192^{\mathrm{NS}}$ & 0.006 & 0.002 & -0.030 & -0.036 & 0.030 & 0.104 & -0.017 & -0.001 & -0.004 \\
\hline \multirow{2}{*}{$\begin{array}{c}\text { Leaf } \\
\text { width }(\mathrm{cm})\end{array}$} & $\mathrm{P}$ & $-0.140^{\mathrm{NS}}$ & -0.008 & -0.012 & -0.028 & -0.051 & 0.023 & 0.020 & -0.125 & -0.092 & 0.036 \\
\hline & $\mathrm{G}$ & $-0.139^{\mathrm{NS}}$ & -0.014 & -0.021 & -0.049 & -0.089 & 0.043 & 0.035 & -0.211 & -0.168 & 0.061 \\
\hline \multirow{2}{*}{$\begin{array}{c}\text { Flag leaf area } \\
\left(\mathrm{cm}^{2}\right)\end{array}$} & $\mathrm{P}$ & $0.019^{\mathrm{NS}}$ & 0.013 & 0.024 & 0.035 & 0.055 & -0.004 & 0.000 & 0.142 & 0.194 & -0.032 \\
\hline & G & $-0.019^{\mathrm{NS}}$ & 0.024 & 0.037 & 0.059 & 0.089 & -0.009 & -0.001 & 0.226 & 0.284 & -0.049 \\
\hline \multirow[t]{2}{*}{ Test weight (g) } & $\mathrm{P}$ & $0.304 * *$ & -0.007 & -0.007 & -0.008 & -0.011 & -0.003 & -0.001 & -0.007 & -0.004 & 0.023 \\
\hline & $\mathrm{G}$ & $0.304 * *$ & 0.01 & 0.010 & 0.012 & 0.016 & 0.004 & 0.001 & 0.010 & 0.006 & 0.033 \\
\hline
\end{tabular}


The estimates of heritability help the plant breeder in selection of elite genotypes from diverse genetic population, hence prior knowledge about the heritability of the traits is a prerequisite for the selection programme (Singh et al., 2011). The broad sense heritability estimates for the traits observed are leaf length (99.88\%), test weight $(99.08 \%)$, days to $50 \%$ flowering $(98.93 \%)$, leaf width $(98.41 \%)$, days to maturity (97.86\%) and least for panicle length $(83.83 \%)$. These results are in collaboration with the results obtained by Abdourasmane et al., (2016) and Akinwale et al., (2011) for days to heading, days to maturity, plant height, grain yield and number of grains per panicle, panicle weight, and panicle length Kundu et al., (2008) for grain yield per plant and 1000 grain weight in tall indicaaman rice and Singh et al., (2007) for days to 50\% flowering, grains per panicle and plant height. The presence of high heritability with high genetic advance showed additive effects of the gene on the character and theyresponse to selection effectively as they are least affected by the environmental condition.

The correlation analysis was done to reveal the association between yield and its component traits. Table 2 presents the phenotypic and the genotypic correlation between yield and its associated traits. The values below the diagonal indicate the phenotypic correlation coefficients of the traits while the values above the diagonal represent the genotypic correlation coefficients of the traits. Genotypic correlations found higher than phenotypic correlations for all the character studied. The direction of phenotypic and genotypic correlations was almost the same for most of the character combinations. Grain yield per plant showed the significant positive correlation number of effective tillers per plant, panicle length and test weight these observations were supported by the results of Baloch et al., (2016), Sravan et al., (2016). Plant height significant positive correlation with a number of effective tillers per plant, panicle length and leaf width. A number of effective tillers per plant showed significant positive correlation with leaf length, leaf width and yield per plant. Thus improvement in yield can be enhanced by indirect selection for effective tillers per plant and leaf width. The results are in conformity with Mohammed et al., (2007) for the number of panicles per plant, Mathure et al., (2011) for the length of panicle and Al-tahir et al., (2014) reported flag leaf length correlation with panicle length.

The path coefficient analysis carried out at phenotypic and genotypic levels showed similar trends for the majority of the traits (Table 3). Path analysis revealed direct and indirect effects on grain yield via yield component traits. At phenotypic level number of effective tillers per plant, panicle length, leaf length, flag leaf area and test weight showed direct positive effect whereas at genotypic level days to maturity, the number of effective tillers per plant, panicle length, leaf length and flag leaf area showed positive direct effect on grain yield per plant. Shankar et al., (2016) reported the positive direct effects coupled with positive correlation coefficients with panicle length and test weight. Hence, selection of the above traits would result in improvement of grain yield in rice. The similar finding also reported by Solanki and Tiwari (2013) and Islam et al., (2015) for days to $50 \%$ flowering, 100 seed weight, panicle length and leaf length had a direct positive effect on grain yield per plant and that will be effective to enhance the grain yield.

\section{References}

Abdourasmane, K. K., Adama, Z., Honore, K., Ambaliou, S., and Alain, A. 2016. Genetic variability and correlation analysis of rice (Oryza sativa L.) inbred lines based on agro-morphological traits. African J. Agric. Res., 11(35): 3340-3346.

Akinwale, M. G., Gregorio, G., Nwilene, F., Akinyele, B. O., Ogunbayo, S. A. and Odiyi, A. C. 2011. Heritability and correlation coefficient analysis for yield and its components in rice (Oryza sativa L.). African J. Pl. Sci., 5(3): 207-212.

Al-tahir, F. M. M., 2014. Flag leaf characteristics and relationship with grain yield and grain 
protein percentage for three cereals. Journal of Medicinal Plants Studies, 2(5): 1-7.

Baloch, A. W., Bhatti, S. M., Baloch, M., Jogi, Q. D., and Kandhro, M. N. 2016. Correlation analysis of various metric traits with grain yield and heritability estimation. Pak. J. Agri., Agril. Engg., Vet. Sci., 32(2): 136142.

Bastia, D., Mishra, T. K. and Das, S. R. 2008. Genetic variability and selection indices forgrain yield in upland rice. Oryza, 45(1): 72-75.

Dewey, D. R., and Lu, K. H. 1959. A correlation and path analysis of components of crested wheat grass seed production. Agron. J., 57: 515-518.

Dhurai, S.Y., Bhati, P. K. and Saroj, S. K. 2014. Studies on Genetic variability for yield and quality characters in rice (Oryza sativa L) under irrigated fertilizer management. The Bioscan, 9(2): 745-478.

Islam, M.A., Raffi, S. A., Hossain, M. A. and Hasan, A. K. 2015. Character association and path analysis of grain yield and yield related traits in some promising early to medium duration rice advanced lines. Intl. J. Expt. Agric., 5(1): 8-12.

Kumar, A., Rangare, N. R. and Vidyakar, V. 2013.Study of genetic variability of Indian and exotic rice germplasms in Allahabad agro climate. The Bioscan, 8(4): 14451451.

Kundu, A., Senapati, B. K., Bakshi, A. and Mandal, G. S. 2008. Genetic variability of panicle characters in tall indicaaman rice.Oryza, 45(4): 320-323.

Mathure, S., Shaikh, A., Renuka, N., Wakte, K., Jawali, N., Thengane, N. and Nadaf, A. 2011.Characterization of aromatic rice (Oryz asativa L.) germplasm and correlation between their agronomic and quality traits. Euphytica, 179: 237-246.

Muhammed, B., Asif, A. K., Anjuman, A., Yusuf. Z. and Muhammad, A. 2007. Path analysis of some leaf and panicle traits affecting grain yield in doubled haploid lines of rice (Oryza sativa L.) J. Agric. Res., 45(4): 248252.

Panse, V. G., and Sukhatne, P. V. 1961.Statistical methods for agricultural workers. 2nd Edn, ICAR, New Delhi. P: 361.

Selvaraj, C. I., Nagarajan, P., Thiyagarajan, K., Bharathi, M. and Rabindran, R. 2011. Genetic parameters of variability, correlation and path coefficient studies for grain yield and other yield attributes among rice blast disease resistant genotypes of rice (Oryza sativa L. African J. Biotechnol., 10(17): 3322-3334.

Shankar, H. P. P., Veni, B. K., Babu, J. D. P. and Rao, V. S. 2016. Assessment of genetic variability and association studies in dry direct sown rice (Oryza sativa L.).Journal of Rice Research, 9(2): 11-16.

Singh, M., Kumar, K., and Singh, R. P. 2007.Study of co-efficient of variation, heritability and genetic advance in hybrid rice. Oryza, 44(2): 160-162.

Singh, S. K., Singh, C. M., and Lal, G. M. 2011. Assessment of genetic variability for yield and its component characters in rice. Oryza, 1(4): 73-76.

Solanki, A., and Tiwari, J. K. 2013. Genetic variability analysis for various yield attributing and quality traits in rice (Oryza Sativa L.). The Bioscan, 8(4): 1403-1407.

Sravan, T., Jaiswal, H. K., Waza, S. A., and Priyanka, K. 2016. Analysis of variability and character association in indigenous aromatic rice (Oryza Sativa L.). Electronic Journal of Plant Breeding, 159-164.

Tuwar, A. K., Singh, S. K., Sharma, A., and Bhati, P. K. 2013. Appraisal of genetic variability for yield and its component characters in rice (Oryza Sativa L.). Biolife, 1(3): 84-89.

\section{How to cite this article:}

Harsha, Indra Deo, Sudhir Kumar and Mohammed Talha. 2017. Assessment of Genetic Variability and Inter-Character Association Studies in Rice Genotypes (Oryza sativa L.). Int.J.Curr.Microbiol.App.Sci. 6(9): 2041-2046. doi: https://doi.org/10.20546/ijcmas.2017.609.251 